Atmos. Chem. Phys., 10, 3353-3364, 2010

www.atmos-chem-phys.net/10/3353/2010/

(C) Author(s) 2010. This work is distributed under

the Creative Commons Attribution 3.0 License.

\title{
Emissions of air-borne mercury from five municipal solid waste landfills in Guiyang and Wuhan, China
}

\author{
Z.-G. Li ${ }^{1}$, X. Feng ${ }^{1}$, P. Li ${ }^{1}$, L. Liang ${ }^{2}$, S.-L. Tang ${ }^{1}$, S.-F. Wang ${ }^{1}$, X.-W. Fu ${ }^{1}$, G.-L. Qiu ${ }^{1}$, and L.-H. Shang ${ }^{1}$ \\ ${ }^{1}$ State Key Laboratory of Environmental Geochemistry, Institute of Geochemistry, Chinese Academy of Sciences, \\ Guiyang, 550002, China \\ ${ }^{2}$ Cebam Analytical, Inc., 18804 North Creek Parkway, Suite 110, Bothell, WA 98011, USA
}

Received: 30 November 2009 - Published in Atmos. Chem. Phys. Discuss.: 20 January 2010

Revised: 31 March 2010 - Accepted: 6 April 2010 - Published: 9 April 2010

\begin{abstract}
China disposes of bulk Municipal Solid Waste (MSW) by landfilling, resulting in a large quantity of mercury that enters landfills through waste. A detailed study on atmospheric mercury emissions from MSW landfills in China is necessary to understand mercury behavior from this source. Between 2003 and 2006, mercury airborne emissions through different pathways, as well as mercury speciation in Landfill Gas (LFG) were measured at 5 MSW landfills in Guiyang and Wuhan, China. The results showed that mercury content in the substrate increased the magnitude of mercury emissions, with the highest emission rate measured at the working face and in uncovered waste areas, and the lowest measured near soil covers and vegetated areas. Meteorological parameters, especially solar radiation, influenced the diurnal pattern of mercury surface-air emissions. Total Gaseous Mercury (TGM) in LFG varied from 2.0 to $1406.0 \mathrm{ng} \mathrm{m}^{-3}$, Monomethyl Mercury (MMHg) and Dimethyl Mercury (DMHg) in LFG averaged at 1.93 and $9.21 \mathrm{ng} \mathrm{m}^{-3}$, and accounted for $0.51 \%$ and $1.79 \%$ of the TGM in the LFG, respectively. Total mercury emitted from the five landfills ranged from 17 to $3300 \mathrm{~g} \mathrm{yr}^{-1}$, with the highest from the working face, then soil covering, and finally the vent pipes.
\end{abstract}

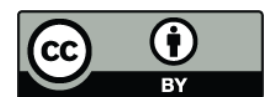

Correspondence to: X. Feng

(fengxinbin@ vip.skleg.cn)

\section{Introduction}

Mercury (Hg) emissions from Municipal Solid Waste (MSW) incineration are regarded as one of the most important anthropogenic mercury sources to the atmosphere (US EPA, 1997; van Velzen et al., 2002). However, about $70 \%$ of MSW globally are deposited in landfills due to their low cost and low maintenance (OECD, 2001). Other researches showed that landfill also served as a potential atmospheric mercury source (e.g. Lindberg and Price, 1999; Kim et al., 2001), and more importantly, landfill sites were effective bioreactors that converted inorganic mercury into methylmercury, the most toxic form of mercury (Lindberg et al., 2001, 2005a; Hawkins and Prestbo, 2004; Prestbo et al., 2003).

China is one of the largest MSW producers in the world, generating over 150 million tonnes MSW per year, which accounts for $29 \%$ of the global total. Landfill is the main disposal method for MSW in China, treating 68.9 million tonnes at 444 landfills in 2004 , accounting for $85.4 \%$ of the total amount of treated waste (including landfill, incineration and compost, the rest was not treated properly, Huang et al., 2006; Liu et al., 2007). The area occupied by MSW landfills in China is about $500 \mathrm{~km}^{2}$, and the volume of buried MSW has reached up to 664 million $\mathrm{m}^{3}$ in 2008 . Mercury enters the landfill mainly through mercury-containing waste, such as batteries, fluorescent lamps and thermometers (US EPA, 1992). Between 1992 and 1999 in China, 185-802 tonnes of mercury was released in the environment from discarded batteries (Yang et al., 2003). Although $\mathrm{Hg}$ content in batteries was lowered since 2001, 153 tonnes of $\mathrm{Hg}$ were still used

Published by Copernicus Publications on behalf of the European Geosciences Union. 
Table 1. Basic situation of the 5 studied MSW landfills.

\begin{tabular}{llcrlll}
\hline City & Landfill site & $\begin{array}{c}\text { Area } \\
\text { (hectares) }\end{array}$ & $\begin{array}{r}\text { MSW disposal } \\
\text { rate } \\
\text { (tonnes day }{ }^{-1} \text { ) }\end{array}$ & $\begin{array}{l}\text { Disposal } \\
\text { method }\end{array}$ & Surface type & $\begin{array}{l}\text { Operation } \\
\text { period }\end{array}$ \\
\hline \multirow{2}{*}{ Guiyang } & G-Y & 52 & 1300 & Sanitary & Covered with temporary soil & $2001-$ \\
\cline { 2 - 7 } & D-Z-W & 10 & 600 & Simple & $\begin{array}{l}\text { Covered with soil and partially } \\
\text { planted with trees }\end{array}$ & $1983-2003$ \\
\cline { 2 - 7 } & X-R-J & 10 & 600 & Simple & $\begin{array}{l}\text { Covered with soil and planted } \\
\text { with grass and trees }\end{array}$ & $1994-2001$ \\
\hline \multirow{2}{*}{ Wuhan } & J-K & 40 & 2200 & Sanitary & $\begin{array}{l}\text { Covered with soil and partially } \\
\text { planted with grass }\end{array}$ & $1989-2005$ \\
\cline { 2 - 7 } & D-S & 20 & & Simple & $\begin{array}{l}\text { Covered with soil and mostly } \\
\text { planted with grass }\end{array}$ & $1989-2007$ \\
\hline
\end{tabular}

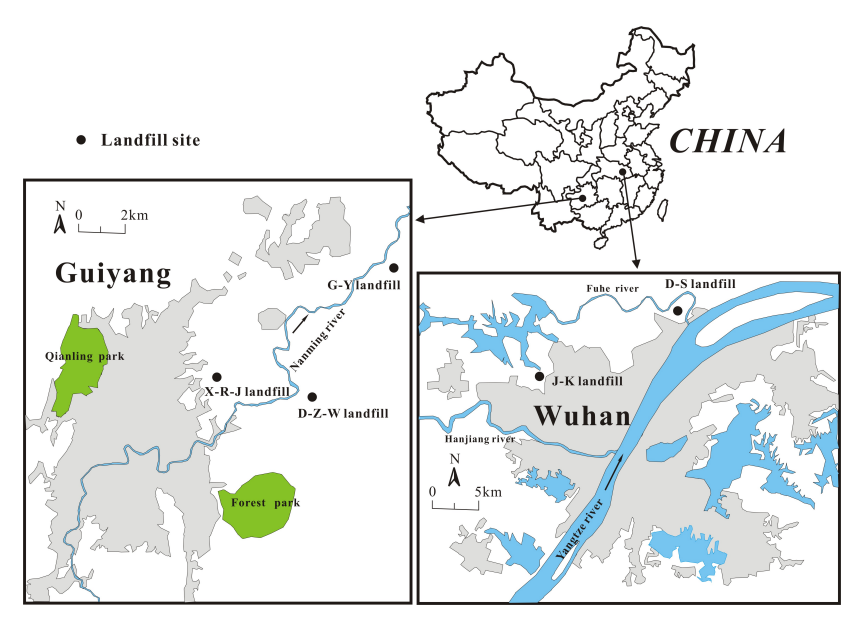

Fig. 1. Sketch map showing the locality of five studied landfills.

in batteries in 2004 (Jian et al., 2008). In fluorescent lamps and thermometers, about 200 tonnes of $\mathrm{Hg}$ are used each year (Hao and Shen, 2006; Shen and Jian, 2004). Because most (over 90\%) of the $\mathrm{Hg}$-containing products were not recycled in China (Yu and Li, 2004), they end up in landfills. Hg emissions from other anthropogenic sources in China, such as coal combustion (Wang et al., 2000, 2010; Tang et al., 2007) and nonferrous metal smelting (Feng et al., 2004a; Li et al., 2009) have been extensively studied, but little information is known about mercury emissions from landfill sites. Unlike other western countries, there are very few facilities that utilize Landfill Gas (LFG) in China (Huang and He, 2008). As a result, almost all the LFG is emitted into the atmosphere directly, which poses a severe ecological risk. Thus, mercury emissions from landfill sites in China deserve investigation.

In this paper we report the results of mercury emissions from $5 \mathrm{MSW}$ landfills in Guiyang and Wuhan city, China, sampled between 2003 and 2006. Hg emissions were measured from two pathways, i.e., landfill surface and landfill vent pipes, and $\mathrm{Hg}$ species in LFG, including total gaseous $\mathrm{Hg}$ (TGM), monomethyl $\mathrm{Hg}$ (MMHg) and dimethyl $\mathrm{Hg}(\mathrm{DMHg})$, were also measured.

\section{Experimental methods}

\subsection{Landfills studied}

Locations of five investigated landfills are given in Fig. 1, basic information is listed in Table 1, and photos showing the sampling sites are shown in Fig. 2. Three landfills are located in Guiyang (capital of Guizhou province), namely GaoYan (G-Y), Da-Zhuan-Wan (D-Z-W) and Xian-Ren-Jiao (XR-J) landfill, and two in Wuhan (capital of Hubei province), namely Jin-Kou (J-K) and Dai-Shan (D-S) landfill. Due to its karstic landscape, landfills in Guiyang are located in valleys, while landfills in Wuhan are located in flat areas. Guiyang has a population of 3.3 million and produces 2100 tonnes of MSW per day, while Wuhan has a population of 7.8 million and produces 6065 tonnes of MSW per day. The climate of both cities is a typical northern subtropical monsoon.

Of the five landfills, two were sanitary landfills (G-Y and $\mathrm{J}-\mathrm{K}$ ), and three (D-Z-W, X-R-J and D-S) were simple landfills. During the study period, three landfills (G-Y, J-K and $\mathrm{D}$-S) were in active operation, while the others were closed. A passive LFG vent system was installed at G-Y and J-K landfills, discharging LFG directly into the ambient air (see Fig. 2d), while the other three landfills did not employ the vent pipe system. The landfills studied are representative of Chinese landfills, since they include different types (sanitary or simple), different stages (operational or closed), and different surface types. 


\subsection{Sampling and analysis methods}

The field sampling campaigns were carried out between 2003 and 2006 at G-Y landfill, while the other 4 landfills were measured in 2004. Monitoring focused on two aspects, namely $\mathrm{Hg}$ surface-air flux and $\mathrm{Hg}$ speciation.

\subsubsection{Hg surface-air flux}

Two methods were applied to measure $\mathrm{Hg}$ surface-air flux, i.e., a Dynamic Flux Chamber (DFC) method for the nonworking face area (Fig. 2c), and a Gaussian plume model for the working face area, where the MSW was dumped, spread, crushed and covered with soil. The principal of DFC measured in conjunction with an automated mercury vapor analyzer (Tekran 2537A) was described elsewhere (Feng et al., 2005; Wang et al., 2005). Briefly, the DFC was a bottom opened, semi-cylinder shaped quartz glass chamber with a rectangular $(20 \times 30 \mathrm{~cm})$ area tight towards the substrate. A turnover time of the air enclosed of was about $10 \mathrm{~s}$. Mercury surface-air flux $F_{\mathrm{Hg}}$ was calculated according to Eq. (1):

$F_{\mathrm{Hg}}=Q \times \frac{\overline{c_{\text {out }}}-\overline{c_{\text {in }}}}{A}$

with a time resolution of $20 \mathrm{~min}$, where $Q$ is the air flow rate through the chamber, $A$ is the area exposed to the surface as well as $\overline{c_{\text {out }}}$ and $\overline{c_{\text {in }}}$ are the mean Total Gaseous Mercury (TGM) concentration measured in the outlet and inlet air, respectively. The Tekran $2537 \mathrm{~A}$ is a sensitive analyzer for TGM with a low detection limit (about $0.1 \mathrm{ng} \mathrm{m}^{-3}$, e.g., Tekran, 1998), and calibrated by its interior mercury vapour source. The chamber blank was $0.5 \pm 1.8 \mathrm{ng} \mathrm{m}^{-2} \mathrm{~h}^{-1}(n=77)$.

The Gaussian plume model (US EPA, 1995) used here is the ISCST3 model (Industrial Source Complex, Short-Term, Version 3), and is expressed as follows,

$c(\mathrm{x}, \mathrm{y})=\frac{Q}{\pi \sigma_{\mathrm{y}} \sigma_{\mathrm{z}} U} \exp \left[-\frac{y^{2}}{2 \sigma_{\mathrm{y}}^{2}}-\frac{(z-h)^{2}}{2 \sigma_{z}^{2}}\right]$

where $C(\mathrm{x}, \mathrm{y})$ is the atmospheric pollutant concentration at the horizontal coordinates $\mathrm{x}, \mathrm{y} ; Q$ is the pollutant emission rate from the source; $U$ is the horizontal wind speed; $h$ is the effective height of pollution source; $\sigma_{\mathrm{y}}$ and $\sigma_{\mathrm{z}}$ are horizontal and vertical dispersion coefficient respectively; $\mathrm{x}, \mathrm{y}, \mathrm{z}$ are Cartesian coordinates.

The working face was treated as a ground surface source, thus the $\mathrm{Hg}$ emission rate can be deduced from the meteorological parameters, and atmospheric $\mathrm{Hg}$ concentration at downwind and upwind working face sites. The dispersion coefficient was calculated through onsite meteorological observations.

\subsubsection{Hg speciation in the LFG}

$\mathrm{Hg}$ speciation in the LFG, including TGM, MMHg and $\mathrm{DMHg}$, was determined at G-Y landfill, while only TGM

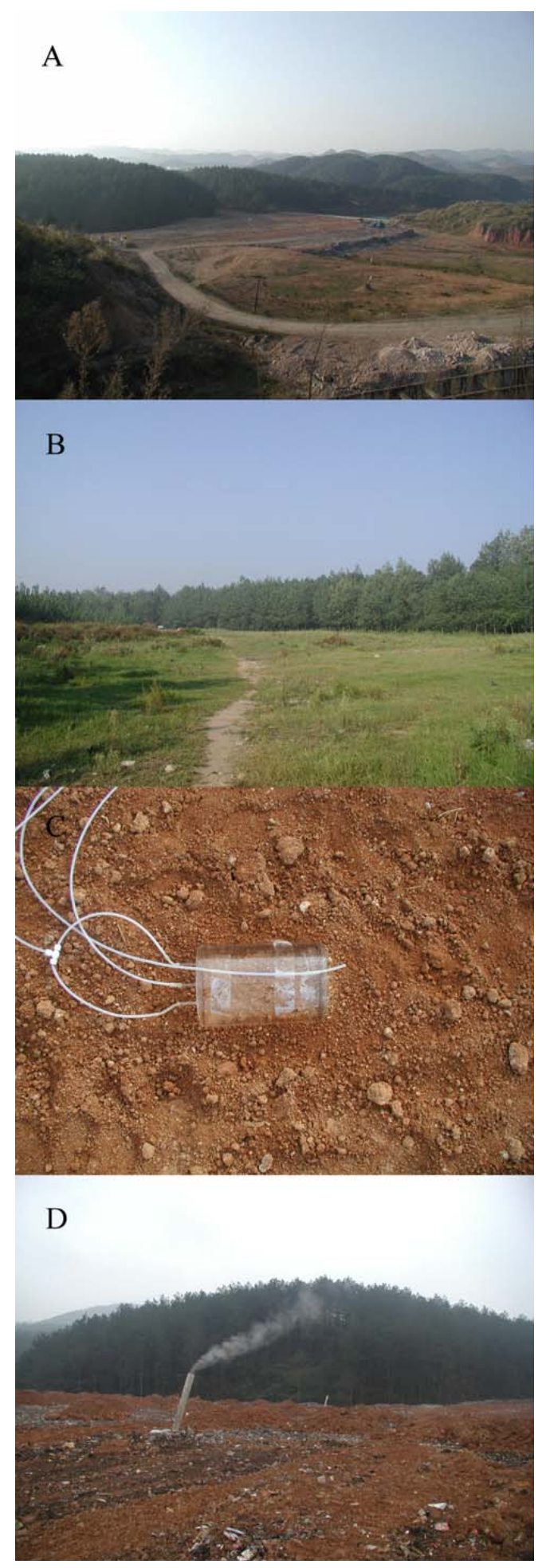

Fig. 2. Photos showing the operation landfill at G-Y (A) and closed landfill at X-R-J (B), the DFC method for surface-air flux at the soil covering area $(\mathbf{C})$ and the vent pipe system for the LFG at G-Y landfill (D). 
Table 2. Statistical summaries of $\mathrm{Hg}, \mathrm{pH}$ and organic matter in the MSW and cover soil at 5 studied landfills.

\begin{tabular}{llllll}
\hline Site and sample type & Analyte & Min & Max & Mean & Std \\
\hline MSW & & & & & \\
Guiyang $(N=42)$ & $\mathrm{Hg}\left(\mathrm{mg} \mathrm{kg}^{-1}\right)$ & 0.170 & 46.222 & 1.796 & 7.072 \\
& $\mathrm{pH}$ & 7.30 & 12.30 & 8.66 & 1.41 \\
& $\mathrm{OM}(\%)$ & 4.91 & 17.84 & 9.82 & 3.24 \\
\hline Wuhan $(N=8)$ & $\mathrm{Hg}\left(\mathrm{mg} \mathrm{kg}^{-1}\right)$ & 0.240 & 1.271 & 0.606 & 0.349 \\
& $\mathrm{pH}$ & 7.50 & 8.30 & 7.86 & 0.24 \\
& $\mathrm{OM}(\%)$ & 5.29 & 12.10 & 7.70 & 2.46 \\
\hline Cover soil & & & & & \\
\hline Guiyang-non-contaminated & $\mathrm{Hg}\left(\mathrm{mg} \mathrm{kg}^{-1}\right)$ & 0.130 & 1.030 & 0.310 & 0.233 \\
areas $(N=23)$ & $\mathrm{pH}$ & 4.90 & 7.70 & 6.25 & 0.85 \\
& $\mathrm{OM}(\%)$ & 0.31 & 5.58 & 1.32 & 1.58 \\
\hline Guiyang-contaminated areas & $\mathrm{Hg}\left(\mathrm{mg} \mathrm{kg}^{-1}\right)$ & 3.124 & 6.527 & 5.132 & 1.473 \\
at D-Z-W landfill & $\mathrm{pH}$ & 8.10 & 8.30 & 8.23 & 0.10 \\
$(N=4)$ & $\mathrm{OM}(\%)$ & 2.64 & 4.55 & 3.80 & 0.91 \\
\hline Wuhan $(N=23)$ & $\mathrm{Hg}\left(\mathrm{mg} \mathrm{kg}^{-1}\right)$ & 0.037 & 0.099 & 0.058 & 0.014 \\
& $\mathrm{pH}$ & 7.10 & 7.90 & 7.59 & 0.23 \\
& $\mathrm{OM}(\%)$ & 0.49 & 1.31 & 0.79 & 0.24 \\
\hline
\end{tabular}

was measured at $\mathrm{J}-\mathrm{K}$ landfill. The sampling and analysis methods for mercury speciation were described by Lindberg et al. (2001) and Bloom et al. (2005). TGM was measured by the Tekran 2537A onsite at $5 \mathrm{~min}$ intervals, and MMHg and DMHg were trapped by diluted $\mathrm{HCl}(0.5 \% \mathrm{v} / \mathrm{v}$ in double deionized water) and Carbotrap ${ }^{\mathrm{TM}}$ adsorbent (20/40 mesh, Supelco Inc., Bellefonte, PA), respectively, with sampling time more than 2 hours. Subsequently, sorbents and aliquots employed to trap organic mercury forms were transported to the laboratory, where DMHg and $\mathrm{MMHg}$ (the latter after aqueous ethylation) were determined by gas-chromatography separation, thermal reduction to $\mathrm{Hg}^{0}$ and CVAFS detection (Tekran Model 2500, Canada). Excessive moisture in LFG was removed by passing the air stream through a condenser (an impinger in ice bath equipped with a soda lime desiccant trap). The Carbotrap ${ }^{\mathrm{TM}}$ was wrapped with aluminum foil during the sampling and storage period to avoid decomposition of the analyte.

MMHg and DMHg in the LFG were calibrated by purging MMHg standard solution (supplied by Cebam Analytical Inc., WA, USA) subjected to ethylation and aliquots of DMHg standard solution (supplied by Jožef Stefan Institute, Ljubljana, Slovenia) respectively onto Carbotrap ${ }^{\mathrm{TM}}$ adsorbents, which being analyzed as described above. During each campaign, the field blank samples for MMHg and DMHg were also collected. The method detection limits for MMHg and DMHg were found to be $0.5-0.6 \mathrm{pg}$ (as mercury) absolute or $1.4-1.7 \mathrm{pg} \mathrm{m}^{-3}$ (for $2 \mathrm{~h}$ sampling) based on 3 times deviation of the blank samples.

\subsubsection{Other parameters}

In addition, $\mathrm{Hg}$ content, $\mathrm{pH}$ and Organic Matter $(\mathrm{OM})$ in the MSW and cover soil of the 5 landfills, TGM in the ambient air above the landfill surface (0.1-2.0 m high), and meteorological parameters, including air/soil temperature, relative humidity, solar radiation, wind speed and wind direction were also monitored to characterize the behavior of $\mathrm{Hg}$ emissions from landfill sites. The meteorological parameters were monitored by using a portable weather station (Global Water IIIB, USA). TGM in the ambient air was determined onsite by Tekran 2537A. Hg content in the MSW and cover soil was analyzed by CVAFS detection (Tekran Model 2500, Canada) after aqua regia $\left(\mathrm{HCl}+\mathrm{HNO}_{3} 3: 1 \mathrm{v} / \mathrm{v}\right)$ digestion. While, $\mathrm{pH}$ and organic matter in the MSW and cover soil were measured by a $\mathrm{pH}$ meter in a $2.5: 1(\mathrm{v} / \mathrm{m})$ water/solid suspension and potassium dichromate method, respectively.

\section{Results and discussion}

\section{1 $\mathrm{Hg}, \mathrm{pH}$ and $\mathrm{OM}$ in the MSW and cover soil}

Table 2 includes $\mathrm{Hg}$, pH and OM content in the MSWs and cover soils. $\mathrm{Hg}$ in MSW was characterized by significant variability (Guiyang, range: $0.170-46.222 \mathrm{mg} \mathrm{kg}^{-1}$, average: $1.796 \pm 7.072 \mathrm{mg} \mathrm{kg}^{-1}, N=42$; Wuhan, range: 0.240 $1.271 \mathrm{mg} \mathrm{kg}^{-1}$, average: $0.606 \pm 0.349 \mathrm{mg} \mathrm{kg}^{-1}, N=8$ ). The result for Wuhan was very similar to that reported by Fang and Hong (1988), where Hg concentrations in MSW 
of Wuhan ranged from 0.13 to $1.53 \mathrm{mg} \mathrm{kg}^{-1}$ and averaged at $0.52 \mathrm{mg} \mathrm{kg}^{-1}(N=20)$. $\mathrm{Hg}$ concentrations in cover soils, in general, were more convergent, with averages of 0.310 and $0.058 \mathrm{mg} \mathrm{kg}^{-1}$ for Guiyang and Wuhan, respectively. These values are similar to typical background levels, including $0.222 \mathrm{mg} \mathrm{kg}^{-1}$ for Guiyang (Wang, 2004) and $0.056 \mathrm{mg} \mathrm{kg}^{-1}$ for Wuhan (Fang and Hong, 1988). A few cover soil samples in D-Z-W landfill contained high $\mathrm{Hg}$ (3.124-6.527 mg kg${ }^{-1}$ ), which may be due to unauthorized dumping of MSW that occurred at this landfill after its closure. $\mathrm{Hg}$ concentration in MSW was higher compared to cover soils, which possibly reflected higher mercurycontained substances in the MSW. Organic matter content and $\mathrm{pH}$ in MSW were also elevated compared to cover soils (Table 2), due to co-mingling of kitchen waste (such as food remnants and leaves, etc.) and coal ash ( $\mathrm{pH} 7.5-12.1$, from the domestic cooking and heating), respectively.

\subsection{TGM in the atmosphere above the landfill}

Figure 3a shows the ranges of TGM concentration observed in the ambient air over the landfills studied. The range of TGM was from 1.6 to $473.7 \mathrm{ng} \mathrm{m}^{-3}$, with averages (Fig. 3b) at different sites ranging from 8.5 to $155.7 \mathrm{ng} \mathrm{m}^{-3}$. The highest TGM concentrations occurred at the working face and the downwind area for all three landfills (G-Y, J-K and D-S), where TGM was sensitive and proportional to the activities of MSW treating at the working face, as observed at operational landfills in Florida, USA (Lindberg et al., 2005b). Lowest TGM was measured at the closed landfill of X-R$\mathrm{J}$, where the whole landfill was planted with grass and trees, and this value was close to average TGM concentrations in ambient air in Guiyang (8.4 $\mathrm{ng} \mathrm{m}^{-3}$, from Feng et al., 2004b). Since the landfills were located far from other urban $\mathrm{Hg}$ emission sources, the elevation of TGM concentrations in the ambient air was predominantly due to the landfill emissions.

\subsection{Hg surface-air fluxes}

\subsubsection{Non-working face areas}

$\mathrm{Hg}$ surface-air fluxes at the non-working face areas, as determined by the DFC method, are listed in Table 3. The flux indicated large variability from site to site, ranging from -286.2 to $5609.6 \mathrm{ng} \mathrm{m}^{-2} \mathrm{~h}^{-1}$, with highest averages of about 500-600 $\mathrm{ng} \mathrm{m}^{-2} \mathrm{~h}^{-1}$ for the sporadically uncovered MSW sites (site F6, F10 in Table 3) and the contaminated soil cover area (site F1), while the lowest was observed at soil covers (site F13, F17) and the grass planted area (F18) with average rates about -1 to $20 \mathrm{ng} \mathrm{m}^{-2} \mathrm{~h}^{-1}$. Hg flux was clearly higher during the warm season for the same surface type, such as "uncovered MSW" sites at warm season (F6 and F10) versus cold season (F14 and F15), and "temporary soil cover" sites at warm season (F8 and F9) versus cold season (F12 and F13).
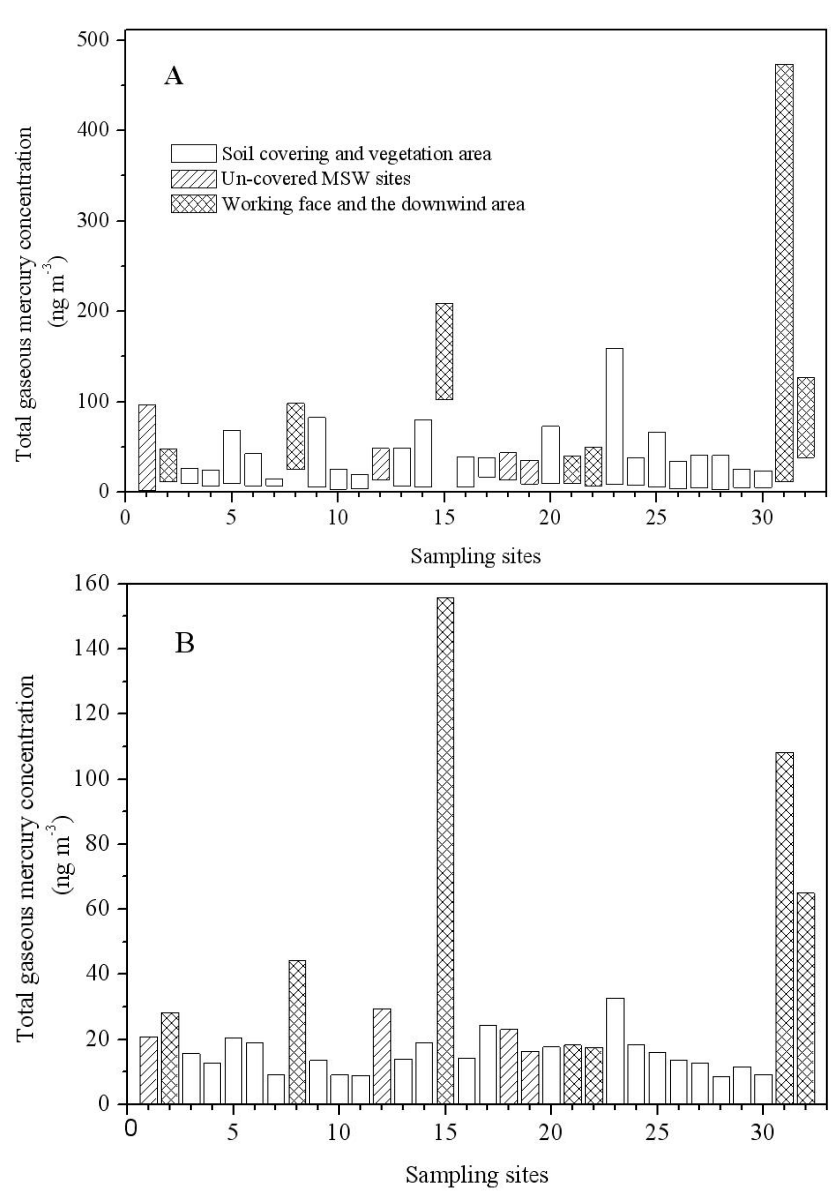

Fig. 3. The range (A) and average (B) of total gaseous mercury in the atmosphere over different sites of the studied landfills (Sample sites: 1-22 at G-Y landfill; 23-27 at D-Z-W landfill; 28 at X-R-J landfill; 29-31 at J-K landfill and 32 at D-S landfill).

The detailed processes of $\mathrm{Hg}$ surface-air flux, as well as the concurrent meteorological parameters at each type of surface are illustrated in Figs. 4-6. Among all parameters, a strong diel cycle with a daytime maximum was observed. Figure 4 shows the contributions of high $\mathrm{Hg}$ content $\left(2.313 \mathrm{mg} \mathrm{kg}^{-1}\right)$ in the MSW to the emission rate. Figure 5 shows how vegetation reduced the mercury emission rate, since the mercury surface-air flux at grass planted area of X-R-J was obviously lower than that of two soil covers (with no plantation) at D-Z-W, although under similar weather conditions and with similar mercury contents in the substrate $\left(0.477-0.575 \mathrm{mg} \mathrm{kg}^{-1}\right)$ among three sites. At two similar soil cover sites of J-K landfill, Hg flux was several folds higher under sunny conditions compared to cloudy and rainy conditions (Fig. 6).

Compared with other studies, $\mathrm{Hg}$ emissions from soil covers were higher than those from several landfills in Florida, USA, which ranged from $1-20 \mathrm{ng} \mathrm{m}^{-2} \mathrm{~h}^{-1}$ (Lindberg and Price, 1999; Lindberg et al., 2005b), but lower compared to a large closed landfill in Seoul, Korea, which 

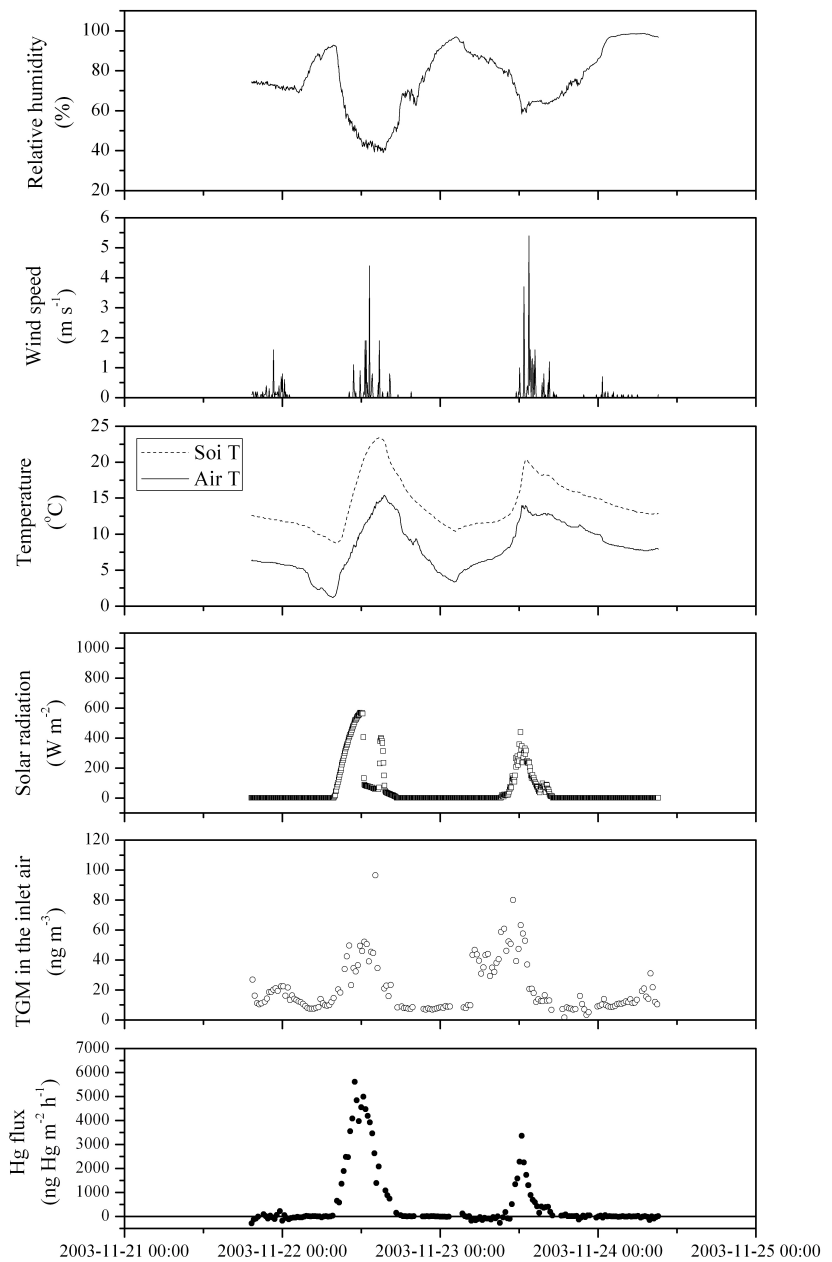

Fig. 4. Mercury surface-air fluxes at un-covered MSW site of G-Y landfill: the contribution of high mercury content in MSW to the mercury emission rate.

averaged $254 \pm 224 \mathrm{ng} \mathrm{m}^{-2} \mathrm{~h}^{-1}$ (Kim et al., 2001). For the uncovered waste, our results obtained in winter 2006 (57.5-84.5 $\mathrm{ng} \mathrm{m}^{-2} \mathrm{~h}^{-1}$ ) were similar to those measured in an American landfill $\left(70 \pm 62 \mathrm{ng} \mathrm{m}^{-2} \mathrm{~h}^{-1}\right.$, Lindberg et al., 2005b). When compared with the mercury emission rate at local and global background sites (typically less than $30 \mathrm{ng} \mathrm{m}^{-2} \mathrm{~h}^{-1}$; Wang et al., 2004; Poissant and Casimir, 1998), $\mathrm{Hg}$ emitted from the landfill soil cover was the same or several times higher, while the uncovered waste was up to several hundreds times higher.

\subsubsection{Working face area}

The calculated $\mathrm{Hg}$ emission rate by the Gaussian plume model indicated the emission rate varied from one to two orders of magnitude between landfills $\left(1.9 \mathrm{mg} \mathrm{Hg} \mathrm{h}^{-1}\right.$ at $\mathrm{D}-\mathrm{S}$ landfill to $369.0 \mathrm{mg} \mathrm{Hg} \mathrm{h}^{-1}$ at G-Y landfill, Table 4). This suggested $\mathrm{Hg}$ emissions from working face were correlated with the MSW disposal rate (Table 1), Hg content in MSW
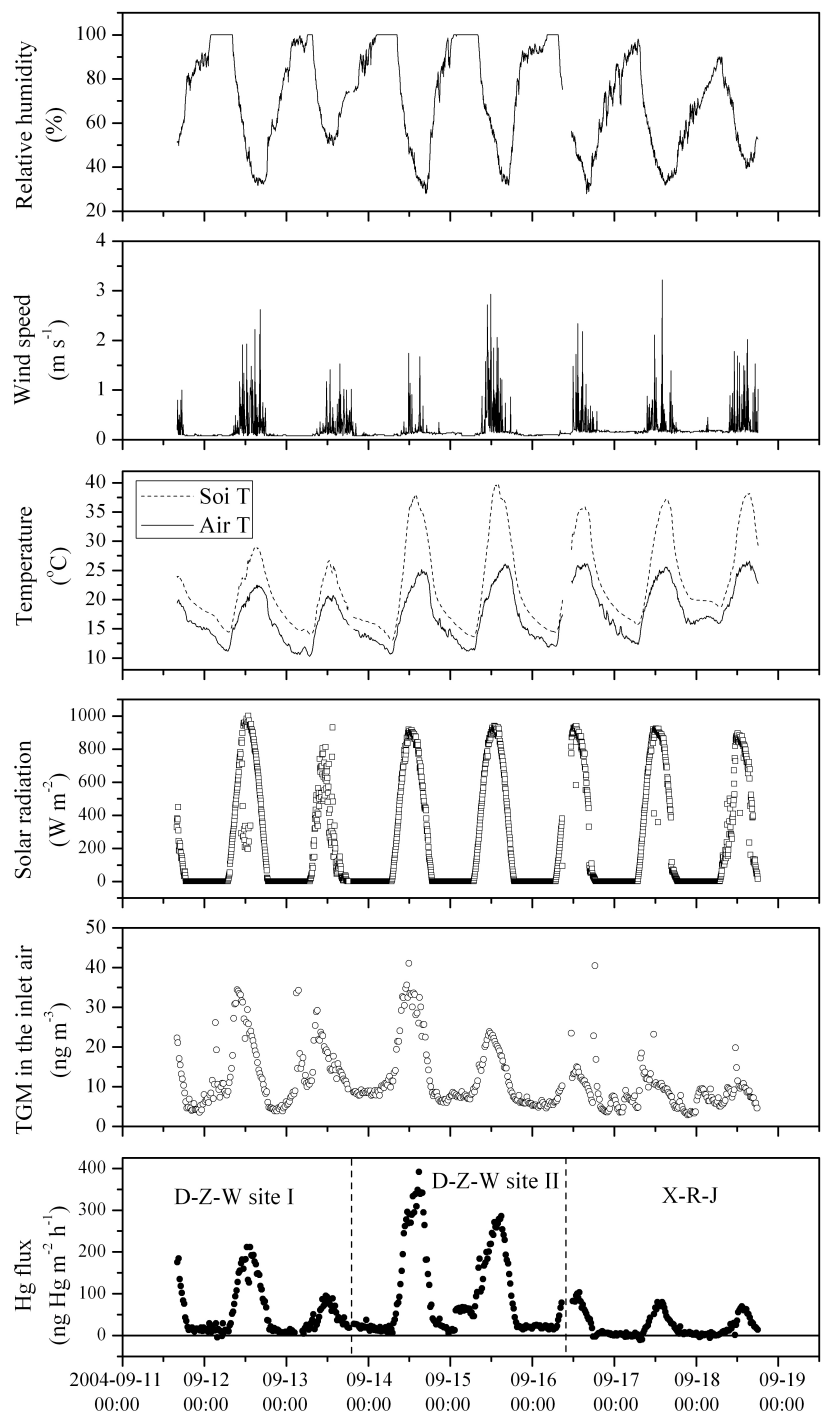

Fig. 5. Mercury surface-air fluxes at soil covering area of D-Z-W and grassed area of X-R-J landfill: the effect of vegetation on the mercury emission reduction.

(Table 2), and the weather conditions at each landfill (Table 4). The emission factors for D-S, J-K and G-Y landfill were $0.04,0.63,6.81 \mathrm{mg} \mathrm{Hg} \mathrm{t}^{-1}$ MSW disposed, respectively. These results were consistent with those from 7 American landfills (0.7-6.6 $\mathrm{mg} \mathrm{t}^{-1}$; Lindberg and Price, 1999; Lindberg et al., 2005b). Hg emission factors indicated that $0.07 \% 0-3.78 \% \mathrm{oHg}$ in MSW was released into ambient air through the working faces, with an average loss rate of $1.63 \%$. When combined with the emission rate and the actual area of the working face, $\mathrm{Hg}$ emissions from the unit area of the working face can been obtained, with a maximum of $57651 \mathrm{ng} \mathrm{m}^{-2} \mathrm{~h}^{-1}$ at G-Y landfill, which was comparable to a landfill in Florida, USA (70 $000 \mathrm{ng} \mathrm{m}^{-2} \mathrm{~h}^{-1}$; Lindberg and Price, 1999). The results showed that the working face has the highest intensity for $\mathrm{Hg}$ emissions among landfill surfaces. 
Table 3. The statistical summary of Hg surface-air flux measured by the DFC method at different non-working face sites.

\begin{tabular}{lllllrrr}
\hline Landfill & Site & Site description & $\begin{array}{l}\text { Sampling } \\
\text { campaign }\end{array}$ & $\begin{array}{l}\text { Weather } \\
\text { condition }\end{array}$ & $\begin{array}{r}\text { Mean } \pm \text { Std } \\
\left(\mathrm{ng} \mathrm{m}^{-2} \mathrm{~h}^{-1}\right)\end{array}$ & $\begin{array}{r}\text { Min-Max } \\
\left(\mathrm{ng} \mathrm{m}^{-2} \mathrm{~h}^{-1}\right)\end{array}$ & $\begin{array}{r}\text { Data } \\
\text { no. }\end{array}$ \\
\hline D-Z-W & F1 & Contaminated soil cover & Mar. 2004 & Sunny & $559.1 \pm 883.3$ & $47.5-3866.5$ & 85 \\
D-Z-W & F2 & Tree planted area & Mar. 2004 & Cloudy & $88.2 \pm 136.2$ & $-65.4-550.9$ & 116 \\
D-Z-W & F3 & Permanent soil cover & Mar. 2004 & Rainy & $53.6 \pm 46.0$ & $-24.0-188.9$ & 91 \\
D-Z-W & F4 & Permanent soil cover & Sep. 2004 & Sunny & $50.7 \pm 55.5$ & $-27.0-211.5$ & 151 \\
D-Z-W & F5 & Permanent soil cover & Sep. 2004 & Sunny & $112.8 \pm 108.1$ & $5.7-391.7$ & 181 \\
G-Y & F6 & Uncovered MSW & Nov. 2003 & Sunny & $664.6 \pm 1341.2$ & $-286.2-5609.6$ & 164 \\
G-Y & F7 & Temporary soil cover & Nov. 2003 & Rainy & $78.8 \pm 77.9$ & $-72.48-308.7$ & 105 \\
G-Y & F8 & Temporary soil cover & Sep. 2004 & Sunny & $183.3 \pm 191.3$ & $27.2-1273.3$ & 144 \\
G-Y & F9 & Temporary soil cover & Sep. 2004 & Sunny & $133.3 \pm 65.8$ & $28.2-260.0$ & 76 \\
G-Y & F10 & Uncovered MSW & Sep. 2004 & Sunny & $537.7 \pm 485.1$ & $63.2-2877.1$ & 34 \\
G-Y & F11 & Temporary soil cover & Sep. 2004 & Cloudy & $27.8 \pm 16.5$ & $-16.1-89.0$ & 71 \\
G-Y & F12 & Temporary soil cover & Jan. 2006 & Sunny & $29.1 \pm 17.5$ & $-47.6-91.0$ & 165 \\
G-Y & F13 & Temporary soil cover & Jan. 2006 & Sunny & $-1.4 \pm 26.2$ & $-36.1-46.6$ & 43 \\
G-Y & F14 & Uncovered MSW & Jan. 2006 & Sunny & $57.5 \pm 83.4$ & $-52.3-275.2$ & 98 \\
G-Y & F15 & Uncovered MSW & Jan. 2006 & Sunny & $84.5 \pm 88.5$ & $-26.4-406.0$ & 133 \\
J-K & F16 & Permanent soil cover & Jun. 2004 & Sunny & $192.5 \pm 245.3$ & $-40.2-1055.4$ & 178 \\
J-K & F17 & Permanent soil cover & Jun. 2004 & Rainy & $19.6 \pm 22.2$ & $-47.2-358.8$ & 235 \\
X-R-J & F18 & Grass planted area & Sep. 2004 & Sunny & $19.7 \pm 27.3$ & $-10.8-103.6$ & 160 \\
\hline
\end{tabular}

Table 4. Hg emission rate from the working face of 3 operational landfills calculated by ISCST3 model.

\begin{tabular}{|c|c|c|c|c|c|c|c|c|c|}
\hline Landfill & $\begin{array}{l}\text { Sampling } \\
\text { campaign }\end{array}$ & $\begin{array}{r}\text { Down } \\
\text { wind } \\
\mathrm{TGM} \\
\left(\mathrm{ng} \mathrm{m}^{-3}\right)\end{array}$ & $\begin{array}{c}\text { Distance } \\
\text { from } \\
\mathrm{WF}(\mathrm{m})\end{array}$ & $\begin{array}{c}\text { Wind } \\
\text { speed } \\
\left(\mathrm{m} \mathrm{s}^{-1}\right)\end{array}$ & $\begin{array}{l}\text { Weather } \\
\text { condition }\end{array}$ & $\begin{array}{c}\text { Atmospheric } \\
\text { stability* }\end{array}$ & $\begin{array}{r}\text { Emission } \\
\text { rate } 1 \\
\left(\mathrm{mg} \mathrm{Hg} \mathrm{h}^{-1}\right)\end{array}$ & $\begin{array}{r}\text { Emission } \\
\text { rate } 2 \\
\left(\mathrm{ng} \mathrm{Hg} \mathrm{m}^{-2} \mathrm{~h}^{-1}\right)\end{array}$ & $\begin{array}{c}\text { Emission } \\
\text { factor } \\
\left(\mathrm{mg} \mathrm{Hg} \mathrm{t}^{-1} \mathrm{MSW}\right)\end{array}$ \\
\hline D-S & Jun. 2004 & 55 & 50 & 0.30 & Cloudy & $\mathrm{D}$ & 1.9 & 291 & 0.04 \\
\hline $\mathrm{J}-\mathrm{K}$ & Jun. 2004 & 98 & 50 & 0.50 & Sunny & A & 58.2 & 9092 & 0.63 \\
\hline G-Y & Sep. 2004 & 145 & 90 & 0.50 & Sunny & $\mathrm{A}$ & 369.0 & 57651 & 6.81 \\
\hline
\end{tabular}

* Determined by the weather conditions. There are six levels (i.e. A, B, C, D, E, F) of atmospheric stability.

\subsubsection{Factors influencing $\mathrm{Hg}$ surface-air fluxes}

From data in Tables 2 and 3 and Figs. 4-6, it can be easily observed that $\mathrm{Hg}$ content in the substrate plays a fundamental role in $\mathrm{Hg}$ emission among different sites, as described by other researchers (Gustin et al., 2000; Wang et al., 2005). In this study, $\mathrm{Hg}$ in the substrate (MSW or cover soil) showed a log-log linear relationship with $\mathrm{Hg}$ flux (Fig. 7). Because $\mathrm{Hg}$ concentration in MSW was obviously higher than that of the cover soils (Table 2), $\mathrm{Hg}$ emissions from uncovered MSW and working face areas were much higher than that of covering soils. The soil cover was found to be an effective barrier preventing mercury emissions.

For the same sampling site, weather conditions affected $\mathrm{Hg}$ fluxes (Figs. 4-6). For example, the flux decreased nearly $50 \%$ between sunshine to moderate sunshine conditions at site F6 as shown in Fig. 4. Correlation analysis showed that $\mathrm{Hg}$ flux was significantly correlated with solar radiation
( $r=0.852, p<0.001)$, followed by soil temperature $(r=0.532$, $p<0.001)$, air temperature $(r=0.347, p<0.001)$, wind speed $(r=0.172, p<0.001)$, and inversely correlated with relative humidity $(r=-0.682, p<0.001)$.

\subsection{Hg species in the landfill gas}

\subsubsection{TGM}

The concentration of TGM in the LFG ranged from 2.0 to $1406.0 \mathrm{ng} \mathrm{m}^{-3}$ for 27 vent pipes at G-Y, and from 5.0 to $74.0 \mathrm{ng} \mathrm{m}^{-3}$ for 6 vent pipes at J-K landfill, respectively. Large variations were observed among different pipes as shown in Fig. 8. Interestingly, for the first time, we found that TGM in the LFG varied under different weather conditions. TGM was much lower and constant on sunny days, but increased sharply during rainfall (Fig. 9). This phenomenon of increasing TGM during rain events may be due to the 

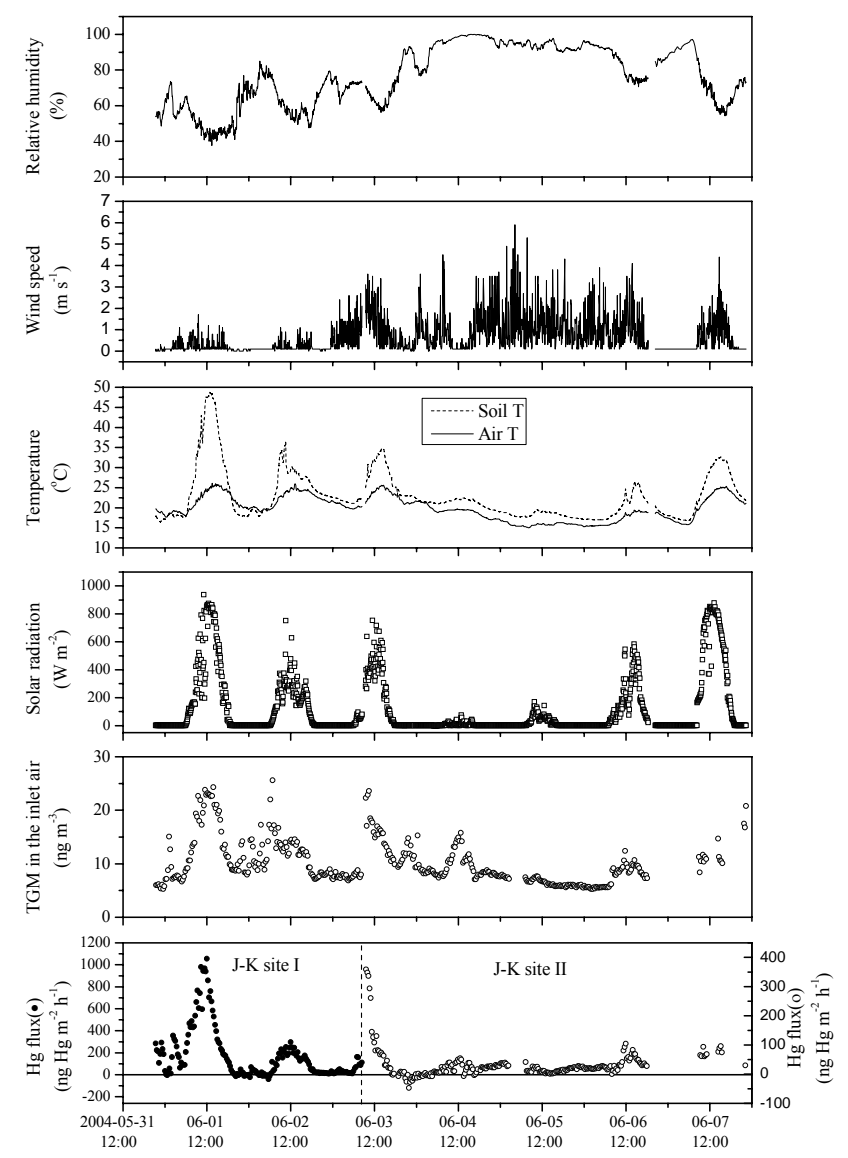

Fig. 6. Mercury surface-air fluxes at soil covering area of J-K landfill: the effect of weather conditions on the mercury emission rate.

following three reasons. First, $\mathrm{Hg}$ in soil pore air inside the landfill was replaced by rain water. Second, the emission pathway of landfill surface was blocked by the rainfall, more LFG was discharged through the vent pipe system. Third, the atmospheric pressure dropped on rainy days, which promoted LFG emission from the passive vent pipes. Many studies reported the flow rate of LFG from passive vent pipes was susceptible to the fluctuation of atmospheric pressure (Gebert and Groengroeft, 2006; Maurice and Lagerkvist, 2003), which generally decreased during the rainfall. We observed an obvious LFG plume from the vent pipes during rainy days as shown in Fig. 2d, whereas imperceptible emissions were found on sunny days. TGM concentrations in LFG increased several fold during the rainfall (Fig. 9), while Hg surface-air flux declined during the rainfall (Fig. 6).

Compared with TGM concentrations in LFG measured at some American landfills, our results were much lower (Lindberg and Price, 1999; Lindberg et al., 2001, 2005a; Hawkins and Prestbo, 2004; Prestbo et al.,2003). In the latter sites, TGM concentrations was approximately at $\mu \mathrm{g} \mathrm{m}^{-3}$ level, with the highest of about $12 \mu \mathrm{g} \mathrm{m}^{-3}$. The results obtained from G-Y and J-K landfill were comparable to landfills in

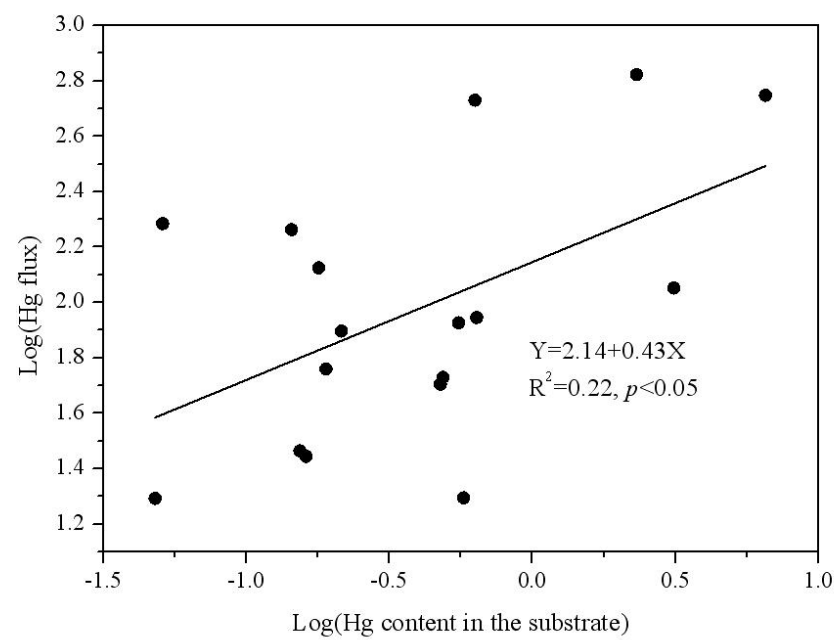

Fig. 7. Correlation between average mercury flux at different sites and mercury content in the corresponding substrates.

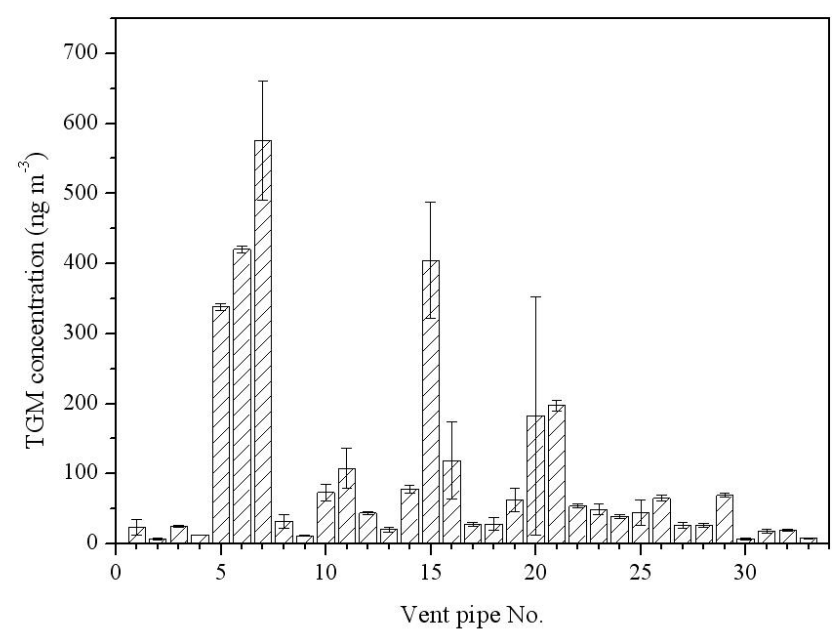

Fig. 8. Average TGM concentrations in the LFG at G-Y (vent pipe No. 1-27) and J-K (vent pipe No. 28-33) landfill, the error bars denote $\pm 1 \mathrm{SD}$ in the measured values.

Sweden (Sommar et al., 1999), Germany (Feldmann et al., 1994), South Korea (Kim and Kim, 2002) and Mexico (de la Rosa et al., 2006), ranging from several to a few of thousand of $n \mathrm{~m} \mathrm{~m}^{-3}$. The great discrepancy of TGM in LFG among different landfills may be due to mercury content in MSW and the method for LFG venting (i.e., active or passive system).

\subsubsection{MMHg}

MMHg in LFG of some vent pipes at G-Y landfill varied between 0.14 and $6.37 \mathrm{ng} \mathrm{m}^{-3}$, with an average of $1.93 \mathrm{ng} \mathrm{m}^{-3}$ (Fig. 10). The percentage of MMHg to TGM ranged from 0.14 to $1.68 \%$, with an average of $0.51 \%$. The global background concentrations of MMHg in the atmosphere are 


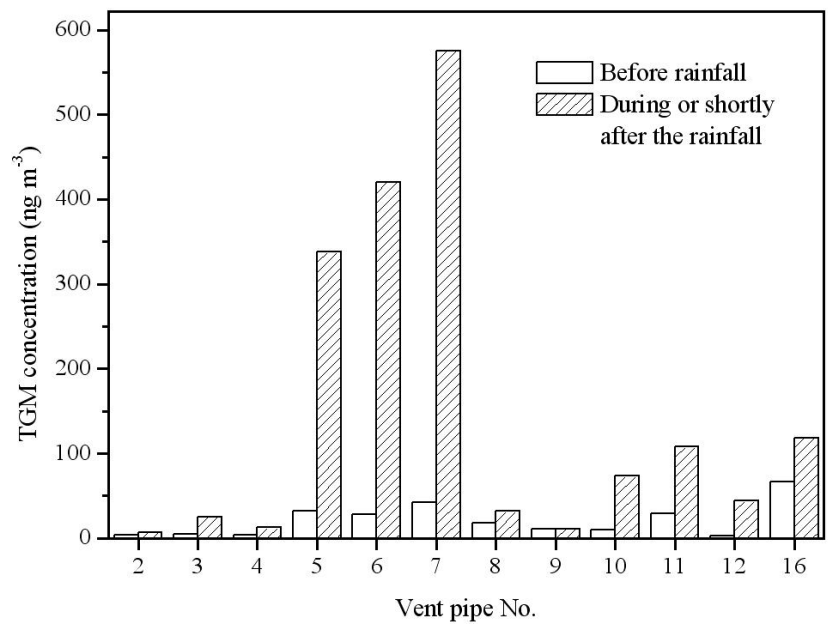

Fig. 9. Comparison of average TGM in the LFG before and after the rainfall event at G-Y landfill.

generally below $10 \mathrm{pg} \mathrm{m}^{-3}$ (Munthe et al., 2003), thus the MMHg in LFG was about 3 orders of magnitude higher than the global background values in ambient air, showing landfill was an important $\mathrm{MMHg}$ emission source. $\mathrm{MMHg}$ concentrations of some American landfills ranged from 1$40 \mathrm{ng} \mathrm{m}^{-3}$, accounting for approximately $0.1 \%$ of TGM (Lindberg et al., 2001, 2005a). These concentrations were much higher than the data observed at G-Y landfill.

\subsubsection{DMHg}

For the same vent pipes sampled for MMHg, DMHg ranged from $2.54-19.05 \mathrm{ng} \mathrm{m}^{-3}$, with an average of $9.21 \mathrm{ng} \mathrm{m}^{-3}$ (Fig. 11). DMHg comprised 0.27 to $3.64 \%$ of TGM in the LFG, with an average of $1.79 \%$. DMHg was also detected in LFG in the USA with concentration between 0.2 to $637 \mathrm{ng} \mathrm{m}^{-3}$ (Hawkins and Prestbo, 2004; Prestbo et al., 2003; Lindberg et al., 2001, 2005a), which were much higher than that observed at G-Y landfill. DMHg is the most toxic mercury species (Nierenberg et al., 1998), and direct emissions from the landfill site could pose a serious ecological risk. It is highly recommended that LFG in China be utilized, or at least burned before it is discharged into the atmosphere. The latter method will decompose methylated $\mathrm{Hg}$ to elemental $\mathrm{Hg}$ at high temperatures, reducing their toxicity. However, from a long run, it's much better to reduce $\mathrm{Hg}$ in products and prevent the $\mathrm{Hg}$-containing waste entering into landfills, this reduction in $\mathrm{Hg}$ from the source is the ultimate way to eliminate the $\mathrm{Hg}$ risk at landfill sites.

\section{Summary and conclusions}

Based on field experiments, $\mathrm{Hg}$ emission patterns from landfills were estimated (Table 5). Total $\mathrm{Hg}$ emissions from the five landfills in 2004 ranged from 17 to $3285 \mathrm{~g} \mathrm{yr}^{-1}$, with

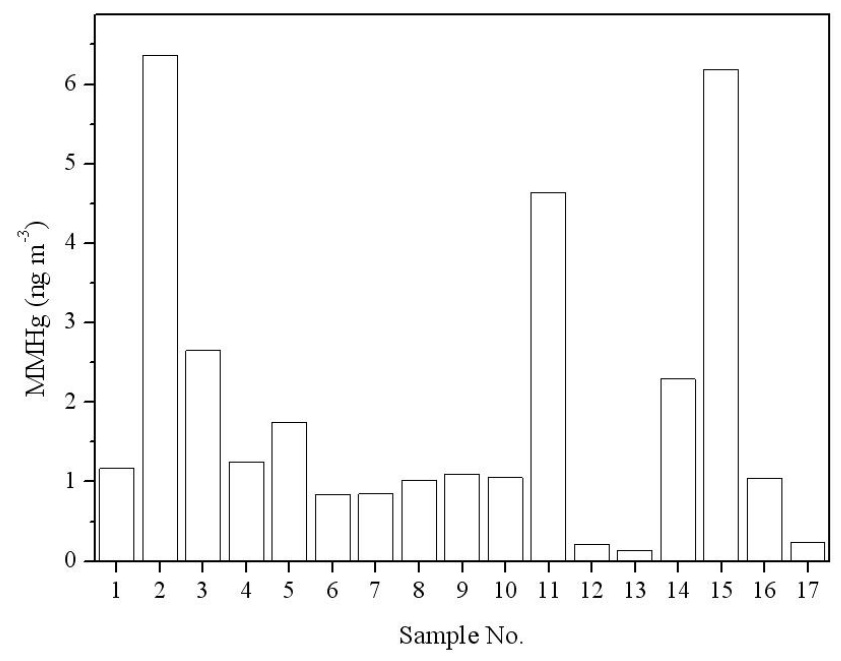

Fig. 10. MMHg in the LFG of selected vent pipes at G-Y landfill.

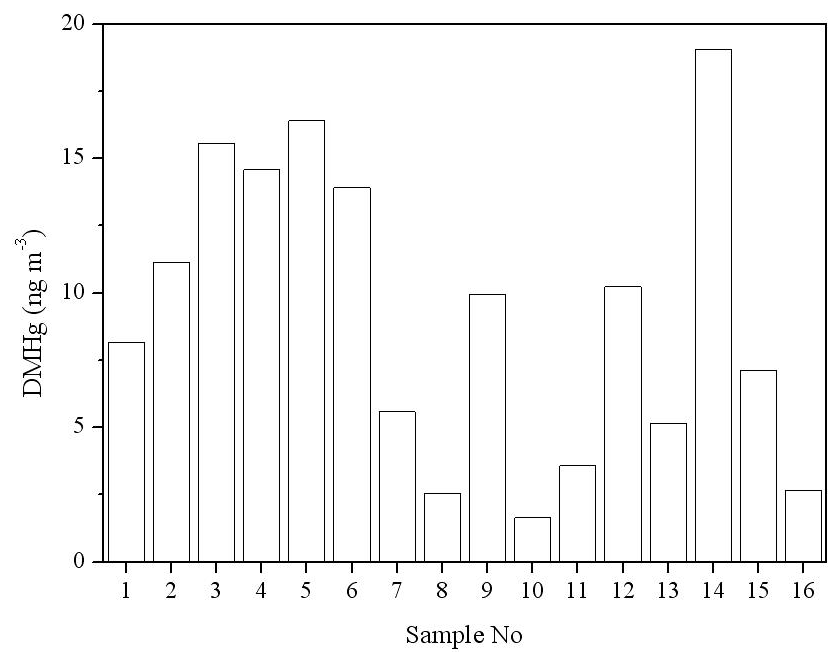

Fig. 11. DMHg in the LFG of selected vent pipes at G-Y landfill.

the highest at G-Y landfill, and the lowest at X-R-J landfill. At G-Y, Hg emissions were dominated by the working face, which accounted for $98.36 \%$ of the total, followed by soil cover (1.28\%), uncovered MSW (0.33\%), and venting pipes $(0.03 \%)$. A similar pattern was also found at $\mathrm{J}-\mathrm{K}$ landfill. This confirmed that the working face was the leading source for $\mathrm{Hg}$ emissions from landfills, and total emissions from the vent pipes were relatively small. A rough picture for $\mathrm{Hg}$ emissions from all landfill sites in China can be obtained by taking into account the total MSW treated by landfill each year, total landfill surface area, total LFG generated and the meteorological data. The estimated $\mathrm{Hg}$ emissions from the Chinese landfill sites ranged from 500$800 \mathrm{~kg} \mathrm{yr}^{-1}$ under different scenarios. These emission fluxes were relatively low compared to the total emissions of 552696 tonnes $\mathrm{Hg} \mathrm{yr}^{-1}$ from Chinese anthropogenic sources 
Table 5. Estimation of annual $\mathrm{Hg}$ emissions from the studied landfills in 2004.

\begin{tabular}{llrr}
\hline Landfill & Emission pathways & Hg emission quantities $\left(\mathrm{g} \mathrm{yr}^{-1}\right)$ & Percentage of each pathway (\%) \\
\hline G-Y & Soil cover & 42.03 & 1.28 \\
& Uncovered waste & 10.95 & 0.33 \\
& Working face & 3231.35 & 98.36 \\
& Vent pipes & 0.93 & 0.03 \\
& Subtotal & 3285.25 & 100.00 \\
\hline J-K & Soil cover & 364.34 & 41.76 \\
& Working face & 505.89 & 57.99 \\
& Vent pipes & 2.20 & 0.25 \\
& Subtotal & 872.43 & 100.00 \\
\hline D-Z-W & Soil cover & 175.86 & 95.58 \\
& Vegetation area & 8.14 & 4.42 \\
& Subtotal & 184.00 & 100.00 \\
\hline D-S & Vegetation area & 33.07 & 69.37 \\
& Working face & 14.60 & 30.63 \\
& Subtotal & 47.67 & 100.00 \\
\hline X-R-J & Vegetation area & 17.53 & 100.00 \\
\hline
\end{tabular}

between 1995-2003 (Wu et al., 2006). However, based on the limited landfill surface, $\mathrm{Hg}$ emission intensity per unit area (up to $57651 \mathrm{ng} \mathrm{m}^{-2} \mathrm{~h}^{-1}$ ) still cannot be overlooked. In conclusion, $\mathrm{Hg}$ emissions from landfill sites depended on the mercury content in the substrate, were maximized at the working face, and were remarkably reduced by applying soil covering or vegetation. $\mathrm{Hg}$ emissions from the landfill surface were sensitive to meteorological parameters, especially solar radiation. In comparison to the vent pipe system, $\mathrm{Hg}$ emissions from landfill surfaces were the primary pathways. Methylated $\mathrm{Hg}$ species produced inside the landfill was especially important, indicated the environmental conditions (such as $\mathrm{pH}, \mathrm{Eh}, \mathrm{T}, \mathrm{O}_{2}$ level), microbial activities (such as sulfate-reducing bacteria which produce reduced sulfur compounds at landfill; Kim et al., 2005), nutrient levels, and the methyl group $\left(\mathrm{CH}_{3-}\right)$ donors, possibly enhanced $\mathrm{Hg}$ methylation. However, the exact mechanisms, whether biological or chemical, are still unknown and further research is needed.

Acknowledgements. This study was financially supported by the National Natural Science Foundation of China (No. 40703024, 40721002, 40703023) and Guizhou Provincial Science and Technology Foundation (No. [2008]2246). The authors would like to thank Sarah Rothenberg and Jonas Sommar for editing our previous manuscript in favour of an improved quality.

Edited by: R. Ebinghaus

\section{References}

Bloom, N. S., Grout, A. K., and Prestbo, E. M.: Development and complete validation of a method for the determination of dimethyl mercury in air and other media, Anal. Chim. Acta, 546(1), 92-101, 2005.

de la Rosa, D. A., Velasco, A., Rosas, A., and Volke-Sepúlveda, T.: Total gaseous mercury and volatile organic compounds measurements at five municipal solid waste disposal sites surrounding the Mexico city metropolitan area, Atmos. Environ., 40(12), 20792088, 2006.

Fang, M. and Liu, H.: Investigation and experiments on the control of heavy metal pollutants in dumping grounds in Wuhan, China Environ. Sci., 8(4), 55-59, 1988.

Feldmann, J., Grümping, R., and Hirner, A. V.: Determination of volatile metal and metalloid compounds in gases from domestic waste deposits with GC-ICP-MS, Fresen. J. Anal. Chem., 350(45), 228-235, 1994.

Feng, X., Li, G., and Qiu, G.: A preliminary study on mercury contamination to the environment from artisanal zinc smelting using indigenous methods in Hezhang county, Guizhou, China Part 1: mercury emission from zinc smelting and its influences on the surface waters, Atmos. Environ., 38(36), 6223-6230, 2004a.

Feng, X., Shang, L., Wang, S., Tang, S., and Zheng, W.: Temporal variation of total gaseous mercury in the air of Guiyang, China, J. Geophys. Res., 109, D03303, doi:10.1029/2003JD004159, 2004b.

Feng, X., Wang, S., Qiu, G., Hou, Y., and Tang, S.: Total gaseous mercury emissions from soil in Guiyang, Guizhou, China, J. Geophys. Res., 110, D14306, doi:10.1029/2004JD005643, 2005.

Gebert, J. and Groengroeft, A.: Passive landfill gas emissionInfluence of atmospheric pressure and implications for the operation of methane-oxidising biofilters, Waste Manage., 26(3), 245-251, 2006. 
Gustin, M. S., Lindberg, S. E., Austin, K., Coolbaugh, M., Vette, A., and Zhang, H.: Assessing the contribution of natural sources to regional atmospheric mercury budgets, Sci. Total Environ., 259(1-3), 61-71, 2000.

Hao, C. and Shen, Y.: Study on production and mercury consumption of clinical mercury-thermometers in China, Res. Environ. Sci., 19(1), 18-21, 2006.

Hawkins, L. and Prestbo, E.: Dimethyl mercury in municipal waste landfill gas: measurements and analytical method development, in: Proceedings of the 7 th international conference on mercury as global pollutant, Ljubljana, 28 June-2 July, 2004.

Huang, Q., Wang, Q., Dong, L., Xi, B., and Zhou, B.: The current situation of solid waste management in China, J. Mater. Cycles Waste, 8(1), 63-69, 2006.

Huang, Y. and He, Q.: Study on the status of output and utilization of landfill gas in China, J. Sichuan Univ. Sci. \& Eng. (Nat. Sci. Ed.), 21(1), 117-120, 2008.

Jian, X., Shen, Y., and Cao, G.: Investigation of mercury usage in the battery production and recommended reduced countermeasures, Environ. Sci. Manage., 33(10), 10-13, 2008.

Kim, K. H., Kim, M. Y., and Lee, G.: The soil-air exchange characteristics of total gaseous mercury from a large scale municipal landfill area, Atmos. Environ., 35(20), 3475-3493, 2001.

Kim, K. H. and Kim, M. Y.: Mercury emissions as landfill gas from a large-scale abandoned landfill site in Seoul, Atmos. Environ., 36(31), 4919-4928, 2002.

Kim, K. H., Choi, Y. J., Jeon, E. C., and Sunwoo, Y.: Characterization of malodorous sulfur compounds in landfill gas, Atmos. Environ., 39(6), 1103-1112, 2005.

Li, G., Feng, X., and Li, Z.: Atmospheric mercury emissions from retort Zn productions, J. Tsinghua Univ. (Sci. \& Tech.), 49(12), 2001-2004, 2009.

Lindberg, S. E. and Price, J.: Airborne emissions of mercury from municipal landfill operations: a short-term measurement study in Florida, J. Air Waste Manage. Assoc., 49(5), 520-532, 1999.

Lindberg, S. E., Wallschlager, D., Prestbo, E. M., Bloom, N. S., Price, J. L., and Reinhart, D.: Methylated mercury species in municipal waste landfill gas sampled in Florida, USA, Atmos. Environ., 35(23), 4011-4015, 2001.

Lindberg, S. E., Southworth, G., Prestbo, E. M., Wallschläger, D., Bogle, M. A., and Price, J.: Gaseous methyl- and inorganic mercury in landfill gas from landfills in Florida, Minnesota, Delaware, and California, Atmos. Environ., 39(2), 249258, 2005a.

Lindberg, S. E., Southworh, G. R., Bogle, M. A., Blasing, T. J., Owens, J., Roy, K., Zhang, H., Kuiken, T., Price, J., Reinhart, D., and Sfeir, H.: Airborne emissions of mercury from municipal solid waste, I: new measurements from six operating landfills in Florida, J. Air Waste Manage. Assoc., 55(7), 859-869, 2005 b.

Liu, J., Liu, J., and Xu, W.: Review and outlook on MSW sanitary landfill technology in China, Environ. Sanit. Eng., 15(4), 58-61, 2007.

Maurice, C. and Lagerkvist, A.: LFG emission measurements in cold climatic conditions: seasonal variations and methane emissions mitigation, Cold Reg. Sci. Technol., 36(1-3), 37-46, 2003.
Munthe, J., Wangberg, I., Iverfeldt, A., Lindqvist, O., Stromberg, D., Sommar, J., Gardfeldt, K., Petersen, G., Ebinghaus, R., Prestbo, E., Larjava, K., and Siemens, V.: Distribution of atmospheric mercury species in Northern Europe: final results from the MOE project, Atmos. Environ., 37(Sup 1), S9-S20, 2003.

Nierenberg, D. W., Nordgren, R. E., Chang, M. B., Siegler, R. W., Blayney, M. B., Hochberg, F., Toribara, T. Y., Cernichiari, E., and Clarkson, T.: Delayed cerebellar disease and death after accidental exposure to dimethylmercury, New Engl. J. Med., 338(23), 1672-1676, 1998.

OECD: Sector case studies: household energy and water consumption and waste generation: trends, environmental impacts and policy responses, (ENV/EPOC/WPNEP(2001)15/FINAL) Organization for Economic Cooperation and Development Environment Directorate 1999-2001 Programme on Sustainable Development, Paris, France, 56-83, 2001.

Poissant, L. and Casimir, A.: Water-air and soil-air exchange rate of total gaseous mercury measured at background sites, Atmos. Environ., 32(5), 883-893, 1998.

Prestbo, E. M., Hawkins, L., Cussen, D., and Fowler, C.: Determination of total and dimethyl mercury in raw landfill gas with site screening for elemental mercury at eight Washington state landfills for the Washington State Department of Ecology, Frontier Geosciences Inc, online available at http://www.ecy.wa. gov/mercury/documents/Mercury_landfill_gas.pdf, last access: 9 April 2010, 2003.

Shen, Y. and Jian, X.: Mercury consumption abatement in China, Res. Environ. Sci., 17(3), 13-15, 2004.

Sommar, J., Feng, X., and Lindqvist, O.: Speciation of volatile mercury species present in digester and deposit gases, Appl. Organomet. Chem., 13(6), 441-445, 1999.

Tang, S., Feng, X., Qiu, J., Yin, G., and Yang, Z.: Mercury speciation and emissions from coal combustion in Guiyang, southwest China, Environ. Res., 105, 175-182, 2007.

Tekran: Model 2357A - Principles of operation, Tekran Inc. Toronto, Canada, 1998.

US EPA: Characterization of products containing mercury in municipal solid waste in the US, 1970-2000, EPA530-S-92-013, US Government Printing Office, Washington, DC, 1992.

US EPA: User's guide for the industrial source complex (ISC3) dispersion models, Volume I - user instructions, Washington, DC, 1995.

US EPA: Mercury study report to congress, Volume II: An inventory of anthropogenic mercury emissions in the United States, United States Environmental Protection Agency EPA-452/R-97004, Office of Air Quality Planning and Standards \& Office of Research and Development, NC, December, 1997.

van Velzen, D., Langenkamp, H., and Herb, G.: Review: Mercury in waste incineration, Waste Manage. Res., 20(6), 556-568, 2002.

Wang, Q., Shen, W., and Ma, Z.: Estimation of mercury emission from coal combustion in China, Environ. Sci. Technol., 34(13), 2711-2713, 2000.

Wang, J.: Study of environmental geochemical baseline of pollutional heavy metals in surficial soil of Guiyang, Guizhou, Doctor dissertation of Institute of Geochemistry, Chinese Academy of Sciences, 2004. 
Wang, S., Feng, X., Qiu, G., and Fu, X.: Comparison of air/soil mercury exchange between warm and cold season in Hongfeng reservoir region, Environ. Sci., 25(1), 123-127, 2004.

Wang, S., Feng, X., Qiu, G., Wei, Z., and Xiao, T.: Mercury emission to atmosphere from Lanmuchang $\mathrm{Hg}$-Tl mining area, Southwestern Guizhou, China, Atmos. Environ., 39(39), 7459-7473, 2005.

Wang, S. X., Zhang, L., Li, G. H., Wu, Y., Hao, J. M., Pirrone, N., Sprovieri, F., and Ancora, M. P.: Mercury emission and speciation of coal-fired power plants in China, Atmos. Chem. Phys., 10, 1183-1192, 2010,

http://www.atmos-chem-phys.net/10/1183/2010/.
Wu, Y., Wang, S., Streets, D. G., Hao, J., Chan, M., and Jiang, J.: Trends in anthropogenic mercury emissions in China from 1995 to 2003, Environ. Sci. Technol., 40(17), 5312-5318, 2006.

Yang, F., Liu, J., and Wang, R.: Estimation on the amount of mercury used in domestic batteries and potential amount of mercury emissions in China, Shanghai Environ. Sci., 22(5), 322328, 2003.

$\mathrm{Yu}, \mathrm{Y}$. and Li, J.: Recovery and disposal of waste battery in China, Sichuan Environ., 23(1), 94-96, 2004. 